\title{
Rethinking the Impact of Microfinance in Africa: 'Business Change' or Social Emancipation
}

\begin{abstract}
Alfred Lakwo, holds a PhD in Development Studies of Radboud University Nijmegen (The Netherlands), is a visiting lecturer in the Institute of Ethics and Development Studies at Uganda Martyrs University, Nkozi, Uganda. His main research focus is microfinance, livelihoods and gender on which he conducted a number of research projects in Uganda.

Alfred.lakwo@gmail.com

PO Box 80, Nebbi Town, Uganda
\end{abstract}

Leo de Haan is Professor of Development Studies and Rector of ISS in The Hague, now the International Institute of Social Studies of Erasmus University Rotterdam. He directed research on commercialization of agriculture, resource conflicts and migration in a number of African countries. His specialization concerns the conceptualization of livelihood research.

rector@iss.nl

PO Box 29776, 2502 LT The Hague

\section{Acknowledgements}

The authors would like to thank two anonymous reviewers, for their useful comments on an earlier draft of this article and Ann Reeves for correcting our English.

Word count article (incl. tables and references): 8442 words 


\title{
Rethinking the Impact of Microfinance in Africa: 'Business Change' or Social Emancipation
}

\begin{abstract}
This paper questions received wisdom that the benefits of microfinance start with poverty reduction and are subsequently followed by social emancipation. Taking the case of Uganda and by using a consensual people-centred relevance test to assess the impact of microfinance on poverty alleviation, microfinance is shown not to improve much the well-being of microfinance clients. Only marginal well-being gains are achieved by clients. However, a subsequent (gender) power relations analysis reveals that in spite of these marginal well-being gains, the women clients achieved more emancipation. The paper calls for a rethinking of the microfinance (outreach) campaign in Africa and of the controversy between a business or welfarist approach to microfinance. The paper suggests that social emancipation should be pursued in its own right rather than waiting for poverty reduction to occur first.
\end{abstract}

(132 words) 


\section{INTRODUCTION}

The Dutch Algemeen Burgelijk Pensioenfonds (ABP), ${ }^{i}$ the world's third-largest pension fund with an invested capital of $€ 215$ billion, ${ }^{\text {ii }}$ doubled its investments in microcredit in Africa, Asia and Latin America in October 2007. Its argument for doing so is that investments in microcredit funds, which are insensitive to macro-economic fluctuations in interest and inflation rates, yield a fair annual return of over $6 \%$, one which correlated well with returns on stocks and bonds before the global credit crunch of 2008 (ABP 2007: 6). Given the current financial crisis, prospects of investments in microcredit funds are still comparatively attractive. ABP's venture into microcredit is a clear sign of the 'business change' that the microfinance sector in Africa is currently experiencing. This change is characterized by a greater emphasis on financial sustainability and profits, i.e. an emphasis on financial returns, than on social returns, i.e. emancipation. Increased financial returns are thought to be synonymous with poverty alleviation. However, we think that argument should not be accepted without striking a blow.

This paper argues that, on the basis of data from Uganda, the emancipation of the disadvantaged in society is more likely to be neglected in the new business climate than their poverty status, which seems easier to improve. The discussion begins with an overview of the academic and policy debate on microfinance as it relates to Sub-Saharan Africa before moving on to the business approach in microfinance. This is followed by an analysis of data from a field survey on microfinance and its effects in Uganda, one of the countries in Africa where microfinance developed early and is currently found in every sector of the economy. The field survey data show that only marginal well-being gains 
are achieved by micro-finance clients. However, a (gender) analysis reveals that in spite of these marginal well-being gains, the clients had more social emancipation. On the basis of this analysis, the concluding section presents a prognosis of the impact of the increased business interest in microfinance on social emancipation and the empowerment of women.

\section{MICROFINANCE IN SUB-SAHARAN AFRICA}

Microfinance, as opposed to microcredit, covers a package of financial services including loans, savings, insurance, leasing, transfers and social intermediation provided by formal, semi-formal and informal institutions (IFAD 2001). It is important to note that Edgecomb and Barton (1998) and Sievers and Vandenberg (2007) explain that 'social intermediation' includes non-financial support provided to prospective borrowers to help them acquire skills and values, which they need to initiate and sustain their microenterprises. This involves training in credit norms and procedures, savings discipline, business management, technical skills, business counselling, marketing information and assistance, product development, appropriate technology development and transfer, and the development of organizations of micro-entrepreneurs.

In Sub-Saharan Africa, the microfinance landscape evolved from two interlinked factors. Firstly, the formal financial sector excluded the poor as commercial banks, established during the post World War II period, exhibited a colonial legacy of financial service provision to urban areas and large-scale export-led projects. Such banks therefore had '[an] intimidating appearance; unhelpful staff attitudes; inconvenient opening hours; 
relatively complicated transaction forms; and [were] perceived as designed for the middle class clients' (Mutesasira et al 1998: 2) to the extent that the poor saw them as 'institutions of thieves'(Dzingira 2002). Zeller (2001: 9) notes that the banks' limited outreach was due to 'fear of default, high costs, and rigid organizational structures inadaptable to high volume, small size loans'.

Secondly, follow-up donor attempts with concessionary loans from development financial institutions - and often with commercial banks - ended up increasingly alienating the bulk of the population. This was because such loans, managed by government officials, targeted either political cronies or specific cash crops such as cotton and coffee in Uganda, or both. Moreover, such donor support was characterized by unsustainable and externally dependent strategies that lacked product diversification. Their focus on credit without savings led to the insolvency of a number of the institutions when external funds were withdrawn under the country's Structural Adjustment Policy (Richardson and Lennon 2001: 1-16 and 20).

However, the Grameen Bank and the BRI provided approaches for a diversified financial landscape that filled and/or replaced the inadequacies of conventional financial institutions. The popularity of microfinance among both development practitioners and poor clients grew from its focus on 'poor people' by adopting a group joint liability (GJL) approach.

Essentially, the 1990s saw the expansion of microfinance as both a replacement of and a complementary service to commercial banking. With a typical characteristic of proximity to clients, speed and flexibility of service, hidden transaction costs, diversity of 
services and products, and mutual reciprocity, microfinance continued to grow into a popular industry all over Africa.

\section{THE ‘BUSINESS CHANGE’ IN MICROFINANCE AND ITS ARRIVAL IN SUB-SAHARAN AFRICA}

Following the World Summit for Social Development in Copenhagen in March 1995 and other subsequent microcredit summits, some leeway emerged for - what is called - a business approach to microfinance. Forums recommended a more pragmatic orientation to dynamic institutional standards rooted in financial performance, increased client outreach and better business practice. The provision of financial access and not subsidies was prioritized, as was support for microfinance institutions (MFIs) instead of clients’ projects; and financing was restricted to institutions that met predetermined performance standards (Lakwo 2007: 34-35). To spearhead the successful introduction of microfinance, the World Bank established the Consultative Group to Assist the Poor (CGAP) to ensure capacity building and institutional strengthening and encourage the spread of best practices in microfinance that emphasize building large-scale financial service systems by adopting commercial banking performance standards (CGAP 1995).

With the commercialization of microfinance, the new objective became financial self-sustainability. The move to sustainability - also known as the institutionalist approach - is based on the argument that 'to contribute to sustainable poverty reduction, MFIs themselves must be viable, sustainable, and growing [since] microfinance is a business, not charity'(IFAD 2001: 5). The decision of the Dutch ABP pension fund, 
highlighted in the introduction, to increase its investment in microcredit funds because they constitute an attractive addition to their investment portfolio, fits this trend perfectly. Likewise, other private sector investment strategies in microfinance increased. For instance, in April 2007, Compartamos, a well known MFI in Mexico sold its 30\% share in the Initial Public Offering (IPO) at US\$ 450 million to private investors. While such private sector funding is seen by Fitch and Sorensen (2007) as relieving the inadequate donor aid funds by making markets work for the poor, Rosenberg (2007) and DaleyHarris (2007) consider it as a 'a boast of credibility of microfinance in commercial markets'. In Uganda, such a change led to the government popularization of savings and credit cooperative societies (SACCOs) at sub district levels.

This business change in microfinance, which has been described as the 'microfinance paradigm shift' (Mayoux 2002) and the 'microfinance schism' (Morduch 2000), has seen the turning of MFIs into banks, the setting-up of village banks, a downscaling by commercial banks and an upscaling by NGOs, and the restructuring of state-owned banks (Dunford 2003: 150). The formalization of MFIs is associated with this change and the adoption of regulatory and supervisory systems in the financial markets is now the norm (Lakwo 2007: 36). This has also led to the preoccupation with issues like microfinance technology and organizational development (Lont and Hospes 2004: 3).

The business change has divided the microfinance industry into opposing camps, i.e. financial sustainability camp on the one hand and poverty alleviation camp on the other hand. In Sub-Saharan Africa, the former consists of powerful CGAP members such as the World Bank, UNDP, USAID, the German GTZ, the UK's DFID and the Dutch 
SNV, among others. They are vying for MFI financial self-sustainability through best practices in a profit-motivated institution-oriented approach. Profit, they argue, attracts private capital and shows a healthy organization (Schreiner and Yaron 2000) in addition to reducing donor dependence. Increasing the impact of MFIs on poverty reduction thus simply requires, according to this camp, wider financial breadth through the expansion and promotion of micro-enterprises that are capable of earning high profits over and above the annual interest rate of the loan, as Barnes et al (2001) baseline study findings in Uganda revealed.

The financial self-sustainability camp therefore calls for large-scale outreach expansion to build revenue to cover costs, reduce the cost-per-unit of loans, and provide for risk minimization between high- and low-profit enterprises (Otero 1994). The UNDP's Microstat optimistically estimates three to seven years for operational sustainability and five to ten years for financial sustainability.

On the other hand, the poverty alleviation camp - taking a welfarist or even charitable view - contends that microfinance accounts for greater poverty reduction amongst its clients. In Sub-Saharan Africa, this camp includes Freedom from Hunger, Women's World Banking and numerous other NGOs. Through credit provision and social intermediation, they argue, microfinance broadens economic development. Subsidies from donors, they insist, should still be used as a catalyst to enable MFIs to deepen financial outreach. This is because subsidies enable MFIs to reduce transaction costs and charge attractive interest rates while passing the benefit on to clients (Morduch 1999). They demonstrate that as donors redirect their subsidy funds to the institutional development of MFIs and not to loan portfolios, they in fact suffocate access to credit 
which in turn perpetuates poverty, especially in the rural areas as the MFIs operating there are unable to secure commercially conditioned capital. Finally, they argue that the enforcement of commercialization ensures that many NGOs will have to discard their 'NGO approach' to poverty reduction as they are compelled to either abandon their microcredit services that the poor so direly need or else forego their other social sectors for a fully fledged microfinance operation (Ditcher 1997: 259). In sum, they maintain that institutional sustainability is incapable of reaching the poorest of the poor. Profit motives are said to strip away any competitive advantage of reaching the poorest of the poor.

No doubt, this cleavage is real and has been a topic of debate at every major international meeting. It was also omnipresent during the UN International Year of Microcredit in 2005, as well as at the African Microcredit Summit in Kampala in 2007. However, Schicks's (2007) publication on the development impact of charitable and sustainable MFIs, which takes the cases of the Grameen Bank in Bangladesh and BancoSol in Bolivia respectively, recommends that the two approaches coexist but with subsidies strategically targeted to allow for greater financial breadth and depth. While Schicks's view offers advantages for building financial sustainability in both charitable and sustainable MFIs, at the samen moment Sievers and Vandenberg (2007) in another publication expound on building sustainability. They propose that both institutional and client sustainability is attainable at the same time by linking MFIs to business development services, which encourage clients to undertake viable and sustainable businesses. In this way, they argue, clients are able to maximize profits allowing them not only to meet loan obligations but also to change their lives. 
With respect to the debate between institutionalists and welfarists we support Sievers and Vandenberg's call (2007) to bridge the differences by focusing on both institutional and client sustainability. However, in our view their conclusion is not unproblematic. With subsidies hard to come by for charitable MFIs, such institutions are limited in their access to funds to pursue their goals. Thus, even if sustainable MFIs continue to co-exist with charitable MFIs - as Schicks suggests - access to financial services for the poor will be curtailed. Secondly and more pertinently (and also encompassing the poverty reduction camp argument), microfinance poverty reduction impacts are lopsided in favour of the economic focus that gives precedence to clients' income generation and increased income levels. This argument too easily overlooks a third position, i.e. that the crux of social gains like women empowerment and emancipation.

So in our view, the debate should not be about which comes first, poverty reduction or sustainable profitability, but rather how these gains promote social emancipation. Indeed, Dunford (2003: 150-151) rightly argues that the different microfinance market segments should be promoted for their own goals rather than attempting to pressure for both social and sustainability objectives as is currently promoted under the market wisdom pressure.

With an analysis of microfinance use among women's groups in Uganda, we demonstrate in the following section that social emancipation - in this case through women's empowerment - is worthwhile as the ultimate motive of microfinance interventions. The analysis shows that social emancipation of clients is the most valuable contribution 
microfinance has made, because it has been a catalyst in allowing clients to transform their social relations.

\section{MICROFINANCE IN NEBBI DISTRICT, UGANDA}

Uganda is no exception to this microfinance controversy. Since the 1990s its microfinance industry has been largely donor-led. The 'business change' between 2000 and 2003 witnessed the emergence of donor-built sustainable and commercially oriented MFIs and the enactment of the Micro Deposit-Taking Institution (MDI) Act in 2004. As of 31 December 2006, MDIs had 143,817 clients, a savings portfolio of USh. 23.3 billion and an average loan of USh 552,790 per client, with 57\% of Ugandans accessing formal financial services (Goodwin-Groen and Latorture 2004). In Nebbi District, where our case study was undertaken, only $9 \%$ of the population had access to financial services (UBOS 2003). Our own survey revealed that $98 \%$ of the population aged 18 years and over lacked access to financial services (Lakwo 2003). As a result, the UNDP established eight MDIs between 1998 and 2004 and facilitated the setting-up of a further seven by the end of 2007

MDIs have, however, received substantial negative publicity from politicians, journalists and academics on account of their high lending rates and aggressive loan recovery methods. As such, the government finds itself in a quagmire, walking away from MDIs in favour of supporting, under the Microfinance Outreach Plan (MOP) and in line with the 2006 presidential election manifesto, the creation and strengthening of Savings and Credit Cooperative Organizations (SACCOs) in every sub-county. 


\section{MICROFINANCE AND ITS IMPACT ON EMPOWERMENT AND SOCIAL EMANCIPATION}

Following an inventory of MFI interventions in Nebbi District six women's groups with a total of 180 members were selected in Alwi Parish. These are client groups and non-client groups. To reduce sample selection bias, study samples were identified by a particular matching approach. Using a pipeline comparison approach, 'would-be-borrowers' were used as control groups (see Mosley 1997). However, the use of this strategy was also based on the lack of baseline information that could have facilitated doubledifference/difference-in-difference and reflexive comparison methods (Baker 2000). Nevertheless, our approach eliminated the problem of sample selection bias common with MFI-engineered homogeneous groups. In striving for quick gains in their

programmes, MFIs sometimes select clients with better endowment status, or conversely in focussing on poverty alleviation sometimes select clients with high poverty scores. We eliminated such bias by using self-founded women groups that had heterogeneous selfselected members. The non-client groups were pipeline client groups, i.e. groups on the waiting list of the Pakwach Nam Cooperative Savings and Credit Society Limited. Thus, the only intervening variable between the two groups was the loan.

Data collection took place in several stages between 2003 and 2006 and included workshops and seminars with donors, an institutional review, focus group discussions, community meetings with sampled women's group members, a household survey, the 
collection of livelihood trajectories through oral histories and semi-structured interviews.

From 2006 onward, a number of follow-up field visits included semi-structured interviews with clients.

\section{Impact on livelihood improvement}

Instead of a simplistic understanding of poverty such as income performance vis-à-vis a national or global poverty line, we adopted an approach that recognizes the multidimensionality of poverty and of poor people's livelihoods.

The use of poverty indicators, which are indicators of economic growth or income, can admittedly be criticized. As de Haan and Zoomers (2005) argues, the quality of human life - or 'the good life' as it is often made operational in livelihood research - is much more than material welfare. Poverty is multidimensional and only a holistic approach will result in a proper understanding of poverty in specific contexts. In livelihood research, an increased awareness has developed that the quality of life means much more than material welfare in terms of income, yield or even health. A holistic approach to livelihoods is necessary in which various dimensions - cultural, social, economic and political - are included in the analysis for a better understanding of the complexity of poverty. Indeed, livelihood research is digging deeper to gain analytical quality. In macroanalyses, simple poverty indicators as GDP/capita are increasingly becoming discredited. They are being replaced by such indicators as the Human Development Index (HDI) and the Chronic Poverty Index (CPI). The HDI is composed of three indicators representing the basic dimensions of human development: a long and healthy life, knowledge and a decent standard of living. The CPI (CPC 2009: 14) is composed of four indicators: 
relatively low GDP per capita and relatively high mortality, fertility and undernourishment.

Consequently, also our micro-analysis needed to go beyond a purely materialistic economic focus (on income and consumption) to one which encompasses multidimensional components such as human (well-being). A research approach was therefore adopted using consistent triangulation (Guion 2004; Wright and J. Copestake 2004) that started with women's everyday problematic worlds and experiences in order to capture the processes that describe and challenge their subjugation (Gorelick 1991) and built on open-ended generative narrative questions (Wright 2003). Women groups on the MFI waiting list in anticipation of microfinance, served as control group (Baker 2000). Multiple units of analysis were used, including individuals, households and the community (Varley 1996). Data collection was organized between 2003 and 2006 in various successive rounds.

A livelihood analysis was applied that could assess the making of a living and derive a meaning from it By looking at how people use the various livelihood endowments and entitlements they have, engage in meaningful activities and achieve different outcomes, the approach provides an avenue within which the multidimensionality of poverty can be assessed. In this way, a member of a society is considered poor if his/her livelihood falls below an acceptable norm according to the prevailing socio-cultural values in that society. Therefore, we opted for a 'good life' perspective that captures what people want and aspire to attain. Such a perspective recognizes that people depend on a diverse array of assets. Assets are 'vehicles for instrumental action (making a living); hermeneutic action (making living meaningful); 
and emancipatory action (challenging the structures under which one makes a living)' (Bebbington 1999).

To facilitate the analysis consistent with this perspective, a Livelihood Endowment Status (LES) was designed. This tool uses the various vital communityidentified assets to test the relevance of external intervention impacts. The assets and strategies act as indicators of change because people stake their lives on them. These indicators, to be used to measure well-being, were identified and prioritized by the community (both men and women). They were used to verify whether or not microfinance interventions enable or constrain such stakes.

The LES is a context-specific tool as it reflects the subjective views of the people. It recognizes the diversity of assets that actors use to adjust, cope and (re)create their living as well as the diversity in their power relations. Unlike conventional livelihood analysis, it does not start with a wealth ranking. LES instead starts with what the people value as requirements for a good life and progresses to locate the position of each category of people according to their endowments derived from a comprehensive summation of all asset portfolios.

$<$ Insert Table 1 $>$

Consequently, the identified and prioritized well-being indicators (see table 1) resulted from numerous community meetings and focus group discussions. It reveals the vital inter-linkages between livelihood assets and strategies on the one hand, and the importance of processes in the maximal realization of desired and appreciated outcomes 
on the other. Such linkages portray the holistic view of life inherent in the multidimensional aspect of people's livelihoods as actors long for a good life in all economic as well as physical, social and political aspects. In addition, it shows the vitality of assets as both a means and an end for a given livelihood strategy. Although the participants, in searching for a good life, demonstrate the integral value of familial relationships, the various processes of access, utilization and transformation of these indicators of well-being are associated with cooperation and conflict. As such, these indicators present the key area in the community where gendered practices and its power wielding and yielding revolve.

$<$ Insert Table 2>

In the LES analysis the direct effects of microfinance were to be found in the difference in LES status between clients (after three years or more of having loans) and non-clients (not yet receiving loans). Table 2 presents a summary of the findings after composite index analysis. The table reveals that, overall, microfinance has not improved the wellbeing of clients relative to that of non-clients. It is evident that, microfinance did improve the financial asset portfolio of clients relative to non-clients. Some marginal gains also occurred in the human and political assets of clients. From this, it can then be argued that microfinance did indeed provide a favourable opportunity for clients to improve their financial, human and political assets. However our second finding refutes the assumption that such improvements make life better for clients compared to non-clients. The table shows that by engaging in microfinance supported activities, clients lost out on 
accumulating or improving their natural, physical and social asset portfolios. Thus the three domains of positive gain were offset by counter-loss in another three domains. This finding shows that, in aggregate terms, microfinance did not improve the well-being of clients any more than that of non-clients, given that both categories had the same endowment status. Given the three-year time span within which clients accessed loans continuously, it can be said that microfinance did not generally improve their overall well-being status compared to that of non-clients.

This finding is not surprising and, for instance, in line with the results of Grimpe's (2002) study of FINCA clients in Uganda that 'loans simply help in muddling through as a short-term relief of securing livelihood [rather] than building a long-term security' (Grimpe 2002: 14).

This part of our analysis therefore contradicts the generally held belief, among both the financial sustainability camp and the poverty alleviation camp, that microfinance is the tar on the road to poverty reduction. It illustrated how microfinance only facilitates to a limited extent a few aspects of clients' well-being. However, the next section shows that a wider arena of social change has to be explored to reveal social gains beyond the scope of the opposing camps.

\section{Impact on empowerment and social emancipation}

Initially, power relations and differences in power remained underexposed in actororiented research on livelihoods of the poor. Following the direction indicated by de Haan and Zoomers (2005) to push the frontier of livelihood and poverty research forward in 
this respect, further analysis was undertaken. Since the client groups under examination consisted entirely of women, power relations were investigated by concentrating on gendered norms in their locality, both formal and informal. The tool developed to enable analysis - Livelihood Entitlement Status (LEnS) - looks at social change from an entitlement perspective, i.e. examining legitimate claims that women (try to) exert as individuals, as members of households and as members of communities. While LES focused on well-being, LEnS elongates the analysis and examines how changes caused by micro-finance - and identified by LES - affects and are affected by power relations.

At each of these levels, the LEnS tool explores the following aspects - inspired by Rowland (1997) - that signify changes in women's agency: (i) at the individual level, attention is paid to women's reflections of themselves in relation to their ascribed ideal image; (ii) at intra-household level, changes in access to livelihood assets and strategies, private property ownership rights, and participation in vital decision-making process are the focus; and (iii) at community level, LEnS explores changes in wider institutional practices to understand whether or not individual and intra-household changes do in fact create social changes in wider community-gendered livelihood practices.

LEnS provides a critical approach to look at power play and is used because it explores the agency of women to recreate their gender relations using the gains, if any, they have attained through microfinance. It focuses on both relational outcomes that actors derive from engaging in making a living, particularly hinging on both the processes and meanings such changes have for their lives.

(1) Changes at an individual level 
Contrary to Mayoux's (2001) findings that solidarity groups increase pressure among members to the point that it can damage the community support system or bring about negative qualifications such as sleepless nights and strained (marital) relationships (Kabeer and Rajasekhar 1997), we found that women clients exhibited their pride both collectively in the focus group discussions and individually during individual interviews when they reminded us to critically view the differences they experience in comparison with others in the community who had not taken out loans.

Second, in contrast to Kabeer's (2001) arguments that credit made little difference to the division of labour as traditional household roles and norms are left intact and women are thus further overburdened by taking on men's roles, we found that women instead gained pride from adopting such male roles as paying poll tax for their husband, paying bride prices for blood-brothers, sharing household income contributions with their husbands and even creating jobs for their husbands. Table 3 shows that among clients, one-quarter of the women take up to share in household income. This pride emanated from the watering down of the traditional symbols associated with these male roles and allowed space to question the further significance of attaching such roles to men.

$<$ Insert Table 3 $>$

Finally, our analysis showed that through engagement in micro-enterprises, women's analytical and enterprise management skills relating to 'best business practice', especially in areas of day-to-day enterprise operations, are increasing. Given that they 
ably manage their enterprises with pride, not least because they have gained functional money management skills, some of the women now even have individual bank accounts.

(2) Changes in intra-household relations

It is clear that livelihood strategies are not only diverse but also gendered in the same way that different household members adopt different strategies. Through participation in microfinance, we found, contrary to Kabeer $(2001 ; 80-82)$, that credit supports the replications of the division of labour as women widened their access to livelihood strategies. Firstly, we found that with microfinancial support, activity diversification takes place. Women microfinance clients have also started to trade in core market areas such as the retail trade in manufactured goods, which was previously done by men. Moreover, some of the activities engaged in, such as fishing, are traditional male domains and are conducted outside the Alwi area - the clients' marital homes. Thus, women are able to move outside their home confines to source stocks to sell. Secondly, it became clear that the shifting pattern of work women are engaging in with microfinance support is also accompanied by a shifting labour value in the community. While non-clients are still relatively trapped in the use of family labour in their enterprises, it is only clients who use hired and paid labour. No hired labour works in enterprises owned by men. Thus, as women operate their enterprises as part and parcel of their household activities, they invest their labour strategically and as these activities compete for labour, hired labour is sought. This shows that women who are involved in micro-enterprises, take on other labourers to share both their domestic work and the running of their businesses in 
their absence. In this way, even if they are away from home for a few days, their role as mother is fulfilled and at the same time their businesses continue to operate.

In addition, comparison between client and control group showed gains in privateproperty ownership rights. Usually women lacked private ownership of livelihood assets and in most cases usufruct rights are granted to them on marriage over money, land and animals. This is because local culture sees them as 'visitors' who should not be given private properties. This trend is changing, as is reflected in the ownership of loans, household assets and livelihood activities. This finding is contrary to 'received wisdom' findings that the stress of work may result in women's loss of control over loans as their husbands take over the decision-making and management of the enterprise. Instead, it tallies with findings that microfinance enhances increased ownership of land and nonland assets among women clients of the Grameen Bank in Bangladesh; gains that increase their feelings of independence in their marital relationships (Osmani 2007). For instance, while a woman may be granted a loan, she does not automatically own it because her husband may take control of the loan. In the analysis, it became clear that although loans are given to women, their husbands gained ownership of some of them, especially of those involving larger amounts. Still in these instances, the women adopted joint ownership strategies to ensure that they too had ownership rights to the loans. Equally, women have through microfinance gained ownership of selected household assets such as poultry, beds and mattresses, their micro-enterprises, and their bank accounts. Other assets such as land, cattle and livestock, and household items such as bicycles and radios are 'gender closed' for women regarding direct ownership. Despite this, women have taken on different strategies such as joint ownership (with their spouse 
or family) of these assets. Such a strategy dents the previous male 'stand alone' ownership of every household asset. And, contrary to the fact that women engage in livelihood activities that are owned by their husbands, female involvement in microenterprises is accompanied by emerging ownership of these activities by women. A significant relationship was found in enterprise ownership. While women themselves own a considerable number of the enterprises, it is only clients who own businesses jointly with their spouses.

Finally, our analysis made it clear that the bargaining roles in ensuring stability in the cooperation and conflict arena within the household are also changing as women's access to money-making markets increases with their active participation in microfinance programmes. Although money used to be seen as 'evil' for women and could only be transacted by men, with the arrival of microfinance programmes in the area, women have gained an arena in which they can make important decisions, collectively and individually, over financial transactions. They, and not their husbands, have made the decisions concerning the loans taken out and their investments. In only a few circumstances was it a joint or family decision. While men do not enter traditional female domains of decision-making, such as the sale of cooked food and beer, women are now slowly penetrating into male domains and deciding to trade in fishing and fish mongering, thus challenging the established norms.

$<$ Insert Table 4> 
Clearly, client women did increase their decision-making power when savings are concerned. When the respondents were asked about who decided on their varied savings made (table 4); clients largely had themselves making the decisions while among nonclients there is almost a shared decision-making responsibility between the individual women and jointly with their husbands. Such a difference in savings decision-making was attributed to the type of savings and therefore is related with micro-finance. While it is easy to decide on cash savings and deposit the cash into one's (micro-finance) bank account, it is difficult to do that discretely if one is going to save in livestock for lack of an account.

Women have joined their household decision-making arenas by trimming down the de facto powers of their husbands. Through joint and family decision-making processes, the husband can no longer make a decision alone before it is implemented by all household members. For example, the power men used to wield over decisions regarding their children's education no longer exists as such decisions are getting taken jointly with their wives. Clients are now empowered to meet the educational costs of their children and are thus able to make decisions alone on expenses without intervention by anyone else.

(3) Changes in community practice

With processes of social change taking place at the individual and intra-household levels, there are inescapable effects for the entire community. From our data it became clear that the spill-over effect of the changes has altered the wider structural framework of the community as women resist institutional practices and become 'models' of change to be 
emulated by others. This influence has, however, been met with mixed results: there has been an acceptance of changes that are considered worthwhile or overdue but resistance to those that are seen as shaking the foundations of the social setting. Although not all community members share the acceptance and/or resistance of these wider changes, at least a number of respondents were in favour of change, as presented below. While the former presents a smooth change transformation process, the latter demonstrates how women are attacking hegemonic practices to gain what they feel is their right. Women's empowerment never comes easily but always has to be fought for.

A number of elders, both men and women, hinted at the community's reconsideration of polygamy. Although polygamy is seen by men as a way of shaking off over-dependence on them by a woman, the women affected are fighting tooth and nail for a 'one-man one-wife' status, using their new-found powers through money to help in their fight. Clients are using their 'cash power' to trap their absconding husbands, thus rendering their co-wives non-competitive as they lack the money with which to provide for themselves.

Likewise, clients are resisting religious dogmatism. Being in an Anglican community, certain religious rules are inherently strong in the community. For instance, trading in alcohol is forbidden and normally taken as a direct route to hell, with people being discouraged from both brewing and consuming it. However in contravention of local custom and by using their loans, a few women have started to publicly sell beer and liquor to the strongly religious group of Anglicans in the area. Gradually, the wider community is realizing that religious dogmatism has been breached to satisfy the interests 
of those 'closer to the church altar'. While they discourage people from doing certain things, they do not provide an alternative.

Women clients were also found to be building some life-time security in their natal homes. Women who have been abused or mistreated by their husbands or who do not totally trust their husbands and in-laws are busy building their fallback positions in their parental home villages. Where men have not conceded to joint ownership and decision-making over livelihood assets and activities, women are often compelled to act secretly to accumulate assets without the knowledge of their husbands and in-laws. Cash is saved for them by friends; livestock are procured and kept with natal brothers (or even fathers); and small businesses are being opened and operated at natal homes. These strategies act as a means of accumulating assets that a woman can use alone without the hurdle of conflict-prone consultations. Such hidden strategies present a power to act gained by women who pursue such devious means, even if they know that the strategies are dangerous for their current marital relations.

Finally, it was ascertained that women clients are enjoining community politics. Through the confidence they have gained from engaging in income generation (both within and outside the kitchen and home), women are gaining acceptance in community politics which until now have been considered a male preserve. Initially women were considered as having no property to be used to turn community decisions into reality. However, with microfinance support, women are gradually gaining power over their voice as they secure assets that upgrade their status from one of being property-less to being a person 'with property'. This new status provides women a position around the community table to discuss community issues with men. As such, women have graduated 
from being mere contributors to projects decided on by men to a position where they enjoy equal decision-making powers on projects and can oversee their implementation as committee members.

\section{(4) To sum up}

The various changes at the individual, intra-household and community levels show how social norms and practices are changing. Contrary to Lairap-Fonderson's (2002) view that microcredit turns women into efficient economic actors placed in the market economy, we found, inherent in the changes, the changing nature of power plays between actors and institutions that are agents of social hegemony. However, although it is admittedly difficult to quantify all the various gains at the different levels of LEnS, especially at the community level, we successfully quantified most of these at the individual and household levels for which the examples provided in tables 3 and 4 serve as illustrations. Therefore, one can conclude that microfinance services have acted as a catalyst in allowing clients to transform their social relations. In spite of marginal gains in wellbeing demonstrated by the LES analysis, the LEnS analysis clearly indicates that a process of empowerment and social emancipation is taking place. Seen from Rowland's (1997) 4-dimensional power analysis, it is evident that women are being empowered in the process of making a living as they challenge their second-class gender position and status, with the result that their self-image (power within) has improved dramatically. Collectively, they are using their power with others to assault male or community dominance. Equally, through their micro-enterprises women are gaining the power to change their household livelihood strategies, access better social services, and own and 
decide about assets in both their marital and natal homes. By so doing, they have established a change in marital relations towards interdependency that reflects a power transformation associated with gains in assuming power over their own lives. Finally, it can be noted that through microfinance, women are gradually challenging hitherto hegemonic gender relations by recreating new gender spaces within which they can live a life of equality. Accompanying such changes are emerging dynamics within the household and community relations regarding access to, ownership of and decisionmaking over livelihood assets and strategies. Consequently, old hegemonic gendered livelihood practices are slowly being permeated and the sanctions that used to reinforce such hegemony are wilting away. This gives women clients the opportunity to slowly enlarge the social boundaries that restricted them in the past.

\section{CONCLUSION}

Since more than a decade the business or institutional approach to microfinance inclined on promoting improved financial performance and financial sustainability, thus increased commercialisation of MFIs. On the other hand, the welfarist approach argues in favour of poverty reduction as the primary objective of microfinance, if necessary supported by subsidies as opposed to the call for cost cutting measures of better business practices. However, we argued that the debate ignores a third and important aspect, i.e social emancipation.

This paper showed that the social emancipation of women in a microfinance programme in Uganda occurred without clear poverty reduction results at the same time. Our analysis in a people-centred relevance test, revealed that microfinance did not improve much the 
well-being of clients as compared to non-clients except for a few positive gains in financial and human asset portfolios. But these marginal gains in well-being have been accompanied by a wider empowerment and social emancipation in the lives of women clients. We have demonstrated that social emancipation - in this case through women's empowerment - is worthwhile as an alternative motive of microfinance interventions. The analysis showed that in this case social emancipation of clients has been a valuable contribution of microfinance.

From these findings, it can be claimed that putting microfinance forward as having double gains - starting with poverty reduction and then followed by social emancipation - is debatable. What the findings call for is that - with the microcredit campaign in Africa increasing microfinance outreach - there is an option to pursue social emancipation in its own right because women's empowerment does not necessarily wait for poverty reduction to occur first. Neither does social emancipation have to occur at the same time and scope with poverty reduction. Thus, the design of microfinance programmes as well as their monitoring and evaluation need to consider an elongated framework for a social emancipation agenda.

We think our findings are not only internally consistent and robust, but also valid for the whole of northern Uganda and relevant to other peripheral, rural areas in SubSahara Africa. Not only face MFIs difficulties in these areas to secure commercially conditioned capital, as we explained in the second section of this paper. Also various kinds of isolation - whether economic, social or physical - from national growth poles and the global economy reduce commercial opportunities in these areas and thus make successful poverty reduction more difficult. This reservation does not necessarily imply 
that we advocate a welfarist approach to microfinance in peripheral areas and a business approach in core areas, but rather that in core areas poverty reduction and social emancipation might be more intertwined. In both areas a social emancipation agenda to microfinance - as a catalyst in allowing clients to transform their social relations constitute a valid third option. 


\section{REFERENCES}

ABP. 2007. ABP Magazine 9: 6.

Anderson, L. and Nina,O. 1998. Microcredit and Group Lending: The Collateral Effects.

Working Paper 18. Aarhus: University of Aarhus.

Baker, J. 2000. Evaluating the Impact of Development Projects on Poverty: A Handbook for Practitioners. Washington: World Bank.

Barnes, C. Gaile, G., and Kibombo, R. 2001. The Impacts of Three Microfinance Programmes in Uganda. http://pdf.dec.org/pdf docs/PNACL035.pdf

Bebbington, A. 1999. 'Capitals and Capabilities: A Framework for Analysing Peasant Viability, Rural Livelihoods and Poverty'. World Development 27 (12): 2021-2044.

CGAP. 1995. Micro and Small Enterprise Finance: Guiding Principles for Selecting and Supporting Intermediaries. Washington: Consultative Group to Assist the Poor http://www.ilo.org/public/english/employment/ent/papers/financgd.htm.

CPC. 2009. Escaping Poverty Traps. Chronic Poverty Report 2008-09. Manchester: Chronic Poverty Research Center. 
Daley-Harris, S. 2007. State of the Microcredit Summit Campaign Report . Washington, D.C.: Microcredit Summit Campaign.

Ditcher, T. 1997. 'Appeasing the Gods of Sustainability: The Future of International NGOs in Microfinance', in D. Hulme and M. Edwards (eds) in association with Save the Children Fund, NGOs, States, and Donors: Too Close for Comfort? pp. 128-139. London: Macmillan Press:

Dunford, C. 2003. 'The holy grail of microfinance: 'Helping the poor' and 'sustianable?', in M. Harper (ed), Microfinance: Evolution, achievements and challenges. pp. 37-51. London: ITDG Publisher

Dzingirac, V. 2002. Saving to Death: A Study of Group Based and Other Saving Arrangements in Rural Chivic District, Zimbabwe http://www.fao.org/sd/ppdirect/Ppre0071.htm

Edgecomb E. and Barton, L. 1998. Social Intermediation and Microfinance Programs: A Literature Review. Washington: Microenterprise Best Practices Project USAID.

Fitch, B. and Sorensen, L. 2007. The case for accelerating profit-making at the base of the pyramid: What could and should the donor community be seeking to do, and what results should it expect? Journal of International Development, 19, pp. 781-792. 
Goodwin-Groen, R. and Latorture, A. 2004. Uganda Microfinance Effectiveness Review. Washington: Consultative Group to Assist the Poor.

Gorelick, S. 1991. 'Contradictions of Feminist Methodology'. Gender and Society 5 (4): $459-477$.

Grimpe, B. 2002. Rural Microfinance Clients in Uganda: FINCA Client Analysis. FSD Series 6. Kampala: Financial System Development Project, Bank of Uganda-GTZ.

Guion, L. 2002. Triangulation: Establishing the Validity of Qualitative Studies. Gainesville: Institute of Food and Agricultural Sciences, University of Florida.

de Haan L., and Zoomers, A. 2005. 'Exploring the Frontier of Livelihood Research'. Development and Change 36 (1): 27-47.

IFAD. 2001. Rural Finance: From Unsustainable Projects to Sustainable Institutions for the Poor. Rome: GMS Grafiche.

Kabeer, N. and Rajasekhar, D. 1997. Micro credit and its Impact on Poverty, Well-being and Gender Equity: Some Evidence from Bangladesh and India. Kerala: International Workshop on 'Gender, Poverty and Well-being: Indicators and Strategies UNRISD, UNDP, CDS. 
Kabeer, N. 2001.'Conflict over Credit: Re-evaluating the Empowerment Potential of Loans to Women in Rural Development'. World Development 29 (1): 63-84.

Lairap-Fonderson, J. 2002. 'The Disciplinary Power of Microcredit. Examples from Kenya and Cameroon' in J. Parpart, S. Rai and K. Staudt (eds), Rethinking empowerment. Gender and development in a global/local world. pp. 183-198. London and New York: Routledge.

Lakwo, A. 2003. Access to Financial Services in Nebbi District, Uganda. Nebbi: Unpublished Reconnaissance Inventory.

Lakwo, A. 2007. Microfinance, Rural Livelihood and Women's Empowerment in Uganda. Leiden: African Studies Centre.

Lont, H. and Hospes, O. 2004. Introduction, in H. Lont and O. Hospes (eds), Livelihood and microfinance. Anthropological and sociological perspectives on savings and debts. pp. 3-24. Delft: Uberen Academic Publishers.

Mayoux, L. 1995. From Viscous to Virtuous Circles? Gender and Microenterprise Development. Geneva: UNRISD.

Mayoux, L. 2001. Tackling the Downside: Social Capital, Women's Empowerment and Microfinance in Cameroon. Development and Change 32 (3): 435-464. 
Mayoux, L. 2002. 'Women's Empowerment versus Sustainability? Towards a New Paradigm in Microfinance Programmes' in B. Lemire, R. Pearson and G. Campbell (eds), Women and Credit: Researching the Past and Refiguring the Future. Oxford/New York: Berg Publishers. 245-269.

Morduch, J. 1999. 'The Microfinance Promise'. Journal of Economic Literature 37 (4): $1569-1614$.

Morduch, J. 2000. 'The Microfinance Schisms.' World Development 28 (4): 617-629.

Mosley, P. (1997), The use of control groups in impact assessments for microfinance.

Geneva: ILO, Enterprise and Cooperative Development Department, Social Finance Unit, Working Paper No. 19.

Mutesasira, L., Sempangi, H., Hulme, D., Rutherford, S., and Wright, A. 1998. Use and Impact of Savings Services among the Poor in Uganda. Kampala: Microsave.

Osmani, L. 2007. ‘A Breakthrough in Women’s Bargaining Power: The Impact of Microcredit.' Journal of International Development 19: 695-716.

Richardson, D. and Lennon, B. 2001. Teaching Old Dogs New Tricks: The Commercialization of Credit Unions. Washington: Microenterprise Best Practices Project USAID. 
Rosenberg, R. (2007) CGPA Reflections on the Compartamos Initial Public Offering: A Case Study on Microfinance Interest Rates and Profits. Focus Note No. 42. Washington, D.C.: CGPA.

Rowland, J. 1997. Questioning women's empowerment: Working with women I Honduras. Oxford: Oxfam UK and Irelands.

Schicks, J. 2007. Development Impact and Coexistence of Sustainable and Charitable Microfinance Institutions: Analysing BancoSol and Grameen Bannk. The European Journal of Development Research 19 (4): 551-568.

Schreiner, M. and Yaron, J. 2000. 'Ways Donors Can Help the Evolution of Sustainable Microfinance Organisations.' Savings and Development 24 (4): 423-437.

Sievers, M. and Vandenberg, P. 2007. 'Synergies through Linkages: Who Benefits from Linking Microfinance to Business Development Services.' World Development 35 (8): $1341-1358$.

UBOS. 2001. Socio-economic Survey Report of Nebbi District. Kampala: Uganda Bureau of Statistics. 
Varley, A. 1996. 'Women Heading Households: Some More Equal than Others?' World Development, 24 (3): 505-520.

Wright, K. 2003. 'Problems? What Problem? We Have None at All. Qualitative Data Collection for Impact Assessment. Getting the Questions Right.' Journal of Microfinance 5 (1):115-138.

Wright K. and Copestake, J. 2004. 'Impact Assessment of Microfinance Using Qualitative Data: Communicating between Social Scientists and Practitioners using QUIP.' Journal of International Development 16: 355-367.

Zeller, M. 2001. 'Promoting Institutional Innovation in Microfinance. Replicating Best Practices is not Enough.' Development and Cooperation 1: 8-11. 
Table 1: Priority indicators of well-being for a Livelihood Endowment Status analysis

\begin{tabular}{|c|c|}
\hline Asset Indicators & Reason for Choice \\
\hline $\begin{array}{l}\text { Natural Assets } \\
\text { Has land of }>3 \text { acres }\end{array}$ & $\begin{array}{l}\text { The primary reason is that one can produce crops in large } \\
\text { quantities for both food and income security. A person is } \\
\text { no longer dependent on unreliable and often corrupt land } \\
\text { rental services. }\end{array}$ \\
\hline $\begin{array}{l}\text { Physical Assets } \\
\text { Has permanent housing unit } \\
\text { Has livestock (cattle, shoat and } \\
\text { poultry) } \\
\text { Has household items (radio, } \\
\text { bicycle and bed/mattress etc.) }\end{array}$ & $\begin{array}{l}\text { The reasons are related to social pride and prestige, such } \\
\text { as: not being bothered with regular housing replacement } \\
\text { that is costly; the ability to pay bride price for children; } \\
\text { meeting social obligations and receiving visitors easily; } \\
\text { being informed and having easy access to the outside } \\
\text { world without constraints; and being able to sleep } \\
\text { 'easily'. }\end{array}$ \\
\hline $\begin{array}{l}\text { Financial Assets } \\
\text { Has a business (an IGA) } \\
\text { Is a waged-employee } \\
\text { Has a bank account }\end{array}$ & $\begin{array}{l}\text { The reasons are linked to future security: having an } \\
\text { assured source of steady cash for changing lifecycle } \\
\text { events. This is either by daily (and/or periodic) earnings, } \\
\text { or the safe custody of whatever income is earned. }\end{array}$ \\
\hline $\begin{array}{l}\text { Human Assets } \\
\text { Has secondary education and } \\
\text { beyond } \\
\text { Receives treatment in a modern } \\
\text { medical facility } \\
\text { Lives in a house with good } \\
\text { sanitary conditions } \\
\text { Eats well (meat, fish and sugar) }\end{array}$ & $\begin{array}{l}\text { The central reasons reveal the need to pay oneself (or } \\
\text { another household member) as a way of ensuring that } \\
\text { one derives the best from one's hard work while making } \\
\text { it possible to continue benefiting from such returns; } \\
\text { being able to find salaried employment and read } \\
\text { 'required signs' with ease; avoiding witchcraft associated } \\
\text { with bad omens practised in traditional medicine; being } \\
\text { able to prevent the burden of illness; and being able to be } \\
\text { regain one's strength after hard work. }\end{array}$ \\
\hline $\begin{array}{l}\text { Social Assets } \\
\text { Member of multiple groups } \\
\text { Sends remittance to natal home } \\
\text { Lives in a monogamous } \\
\text { relationship } \\
\text { Faces no domestic violence } \\
\text { (beating, barking, sexual abuse) }\end{array}$ & $\begin{array}{l}\text { Here the community looks at strengthening their social } \\
\text { harmony by building a wider network of support in times } \\
\text { of problems; setting up a situation of being accepted } \\
\text { when a marriage fails or after a spouse's death; } \\
\text { concentrating asset acquisition and improvement within a } \\
\text { family; and reducing physical and emotional harm and } \\
\text { shame for oneself and the community. }\end{array}$ \\
\hline $\begin{array}{l}\text { Political Assets } \\
\text { Elected political leader or } \\
\text { committee member } \\
\text { Participates in community } \\
\text { development programmes } \\
\text { (planning, implementation, and } \\
\text { monitoring + evaluation stage) }\end{array}$ & $\begin{array}{l}\text { The emphasis here relates to wider community } \\
\text { interaction to benefit from government and NGO } \\
\text { resources; being able to voice concerns and needs; and } \\
\text { having a sense of ownership of development initiatives. }\end{array}$ \\
\hline
\end{tabular}

Source: Community meetings 
Table 2 - Summary of livelihood asset portfolio index

\begin{tabular}{|l|r|r|r|r|r|r|}
\hline \multirow{2}{*}{$\begin{array}{l}\text { Asset cluster } \\
\text { portfolio }\end{array}$} & \multicolumn{3}{|c|}{ Clients } & \multicolumn{3}{|c|}{ Non-clients } \\
\cline { 2 - 7 } & Observed & Expected & Index & Observed & Expected & Index \\
\hline Natural asset & 68 & 79 & 0.86 & 71 & 77 & 0.92 \\
\hline Physical asset & 363 & 553 & 0.66 & 394 & 539 & 0.73 \\
\hline Financial asset & 106 & 237 & 0.45 & 87 & 231 & 0.38 \\
\hline Human asset & 821 & 1027 & 0.80 & 768 & 1001 & 0.77 \\
\hline Social asset & 150 & 474 & 0.32 & 153 & 462 & 0.33 \\
\hline Political asset & 217 & 316 & 0.69 & 208 & 308 & 0.68 \\
\hline $\begin{array}{l}\text { LES Overall asset } \\
\text { portfolio status }\end{array}$ & 1,725 & 2,686 & 0.64 & 1,681 & 2,618 & 0.64 \\
\hline
\end{tabular}

Source: Household survey by Lakwo

Table 3 - Distribution of shared contributions to household income

\begin{tabular}{|l|r|r|r|}
\hline \multirow{2}{*}{ Category } & \multicolumn{2}{|l|}{ Contribution to household income } & \multirow{2}{*}{ Total } \\
\cline { 2 - 3 } & $\begin{array}{l}\text { Husband } \\
\text { contributes } 100 \%\end{array}$ & $\begin{array}{l}\text { Husband and } \\
\text { wife equally } \\
\text { contributes }\end{array}$ & \\
\hline Clients & $74.7 \%$ & $25.3 \%$ & $100.0 \%$ \\
\hline Non-clients & $100.0 \%$ & - & $100.0 \%$ \\
\hline Total & $87.2 \%$ & $12.8 \%$ & $100.0 \%$ \\
\hline
\end{tabular}

$V=.379$, sig. $=.000^{*}$ at $p<.05, N=156$.

Source: Household survey by Lakwo

Table 4 Decision-maker on saving by forms of savings

\begin{tabular}{|c|c|c|c|c|}
\hline \multirow[t]{2}{*}{ Category } & \multirow[t]{2}{*}{ Forms of savings } & \multicolumn{2}{|c|}{ Who decide } & \multirow[t]{2}{*}{ Total } \\
\hline & & Self & Joint & \\
\hline \multirow{5}{*}{$\begin{array}{l}\text { Clients } \\
(\mathrm{V}=.473, \\
\text { sig. }=.010^{*}, \\
\mathrm{~N}=41)\end{array}$} & Cash & $73.2 \%$ & $14.6 \%$ & $87.8 \%$ \\
\hline & Livestock & - & $4.9 \%$ & $4.9 \%$ \\
\hline & Both cash and Livestock & $7.3 \%$ & - & $7.3 \%$ \\
\hline & Education & - & - & 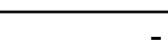 \\
\hline & Total & $80.5 \%$ & $19.5 \%$ & $100.0 \%$ \\
\hline \multirow{5}{*}{$\begin{array}{l}\text { Non- } \\
\text { clients } \\
(\mathrm{V}=.696, \\
\text { sig. }=.000^{*} \text {, } \\
\mathrm{N}=77)\end{array}$} & Cash & $35.1 \%$ & $3.9 \%$ & $39.0 \%$ \\
\hline & Livestock & $20.8 \%$ & $15.6 \%$ & $36.4 \%$ \\
\hline & Both cash and Livestock & $3.9 \%$ & - & $3.9 \%$ \\
\hline & Education & - & $20.8 \%$ & $20.8 \%$ \\
\hline & Total & $59.7 \%$ & $40.3 \%$ & $100.0 \%$ \\
\hline
\end{tabular}

$*$ denotes significant at $p<.05$

Source: Household survey by Lakwo 
ENDNOTES 
${ }^{\mathrm{i}}$ The ABP is the pension fund of 2.6 million Dutch civil servants and assures income security for its members and their families in cases of disability and death, and in retirement.

ii This figure is equal to at least half the Gross Domestic Product (GDP) of the whole of Sub-Saharan Africa produced by over 750 million people. 